\title{
Sustainable Development Interfaces: a case of NGO Intervention in a Frontier Settlement in Pará
}

Kei Otsuki: MSc in Global Agricultural Sciences, both from the University of Tokyo - Japan, $\mathrm{PhD}$ in Social Sciences from Wageningen University at Wageningen in the Netherlands. Currently is research associate in International Cooperation and Development Section of UNU-ISP. E-mail: kei.otsuki@gmail.com

\section{Resumo}

Embora desenvolvimento sustentável tenha sido popularizado na Amazônia brasileira e a literatura sobre sua prática já seja abundante, pouco tem sido discutido sobre o que realmente acontece com a implementação dos projetos. Este artigo busca preencher esta lacuna utilizando a análise de interfaces, que permite ao analista examinar espaços criados através de interações entre os vários atores envolvidos no processo dos projetos de desenvolvimento sustentável. $\mathrm{O}$ artigo baseia-se em um projeto de manejo de base comunitária de recursos naturais iniciado por uma organização não-governamental brasileira no sudeste do estado do Pará e discute a importância de esclarecer os diferentes corpos de conhecimento e exercícios da capacidade de ação dos atores (agência) para a promoção do desenvovimento sustentável.

\begin{abstract}
Although sustainable development has been popularized in the Brazilian Amazon and literature on its theory and practice abounds, little has been discussed about what it actually does as a project implemented on the ground. This article aims to fill this gap by using an interface analysis, which allows the analyst to examine spaces created through interactions among the various actors involved in the sustainable development project process. The article draws on a community-based natural resource management project initiated by a Brazilian non-governmental organization in the south-east of the state of Pará and discusses the importance of clarifying different bodies of knowledge and exercises of agency in the promotion of sustainable development.
\end{abstract}

\section{Palavras-chave}

Desenvolvimento Sustentável. Interface. Amazônia

\section{Keywords}

Sustainable Development. Interface. Amazon 


\section{INTRODUCTION}

During the 1990s, sustainable development of the Brazilian Amazon was placed firmly on the national and international policy agenda (KOLK, 1996). Since then, scientists have been monitoring the state of the largest remaining rainforest of the world alarmed by its rapid disappearance, and governmental and non-governmental organizations (NGOs) have continually implemented natural resource conservation and forest management projects (see HOCHSTETLER; KECK, 2007, chapter 4 for a recent review). Nevertheless, the deforestation rate remained high in the Amazon during the 2000s, particularly in frontier settlements demarcated in the process of agrarian reform in the states of Mato Grosso, Pará and Rondônia (BRANDÃO JR.; SOUZA JR., 2006). ${ }^{1}$

Scholars have attributed the difficulties of environmental policy intervention in these frontier settlements to rapid urbanization (BROWDER; GODFREY, 1997), precarious land tenure (FEARNSIDE, 2001), weak frontier governance (NEPSTAD et al., 2001), and inadequate timber policy (NEPSTAD et al., 2004). These difficulties are in fact rooted in sets of policies that had previously encouraged deforestation through the state-led frontier-making in the Amazon and contestations among a wide range of actors who were mobilized in this process (FEARNSIDE, 2005). During this frontier-making, such social actors as landless farmers, loggers, land speculators, large companies, and federal agencies laid competing claims to natural resources and economic power, generating land conflicts, political disputes, and rural violence (SCHMINK; WOODS, 1992). With the introduction of sustainable development, these contestations have intensified, as both "the social driving and mitigating forces of deforestation in the Amazon are extremely complex" (PERZ, 2001, p. 48, emphasis added), involving a larger number of actors, such as environmental advocacy groups, forest agencies, various kinds of NGOs, and international organizations.

Sociological inquiries into the complexity of contestations in the Amazon have conventionally built on the analysis of modernization (D'INCAO; SILVEIRA, 1994) and changing demographic characteristics and household strategies associated with land use (BROWDER et al., 2008; PERZ, 2001). These studies have made a significant contribution to our broader knowledge of the socioeconomic dynamics of frontier expansion and Amazonian development.

The agrarian reform settlement areas in Brazilian Amazonia coincide with the area known as Arco do Desmatamento.
Few studies, however, have discussed the nature of the contestations themselves. As a consequence, we do not yet understand how the contestations among different social actors create new situations and influence social change when frontier settlements are established and new societies emerge. Understanding the characteristics of the contestations and social change is crucial to insure sustainability of environmental management because sustainable development needs to be compatible with local engagement and movements that insure the engagement (ELLIOT, 1999[1994]; RUSCHEINSKY, 2004), and people who are surrounded by the environment at stake should ultimately find the ideal of sustainable development relevant in their social context.

Development sociology ${ }^{2}$ offers an analytical tool for looking into the contestations described, especially by clarifying how each social actor attaches values and meanings to sustainability (cf. ARCE, 2003). According to this focus, the contestations are principal sources of social change which demonstrate the capacity of the involved actors and indicate possibilities for their further engagement. Such a view is underpinned by an earlier definition of sites of development as "battlefields" in which different perceptions, organizing practices, bodies of knowledge, and experiences interact with each other and create new space for change in an actual project process (LONG; LONG, 1992). In order to grasp the Amazonian societies' capacity to be engaged with sustainable development, the analyst needs to pay close attention to the battlefields of sustainable development and the emergence of a new space in which natural resource management is negotiated (LEEUWIS, 2000).

Methodologically, this space is most effectively explored by following the encounters of social actors at an "interface." According to Long (2001, p. 65), "interfaces typically occur at points where different, and often conflicting, lifeworlds...intersect." A life-world represents a set of "biographically determined situations," which cannot be determined prior to the happening of events (SCHUTZ, 1970, p. 73), and the encounter between various life-worlds creates "unpredictable" social outcomes in relation to development planning (LONG, 1989). By focusing on these encounters, the analyst follows "processes of planned intervention", "processes of participation and non-participation in the intervention" and "the relationships" between the "external" and "local" processes (LONG, 1989, p. 3-5). These various processes demonstrate the nature and extent

For what development sociology might represent, see Booth (1994) and Long (2001). 
of the "room for maneuver" in the planning, which cannot be properly explained through institutional results of the policy intervention (CLAY; SCHAFFER, 1984).

Using interface analysis, this paper aims to explore how discourses and practices of sustainable development create layers of encounters and how the microdynamics of interactions are shaped at each layer. The paper uses a case study of a community-based natural resource management project implemented by a Brazilian NGO in the south-east of the state of Pará to look into the dynamics observed at interfaces in the project process. Before introducing the case study, however, the paper needs to introduce some principal concepts that are useful for the interface analysis: social domain, arena, knowledge, and agency. The case study is elaborated chronologically, in such a way as to detail encounters between posseiros, técnicos and development experts and new situations emerging in the project process. The ethnographic data used in the case study have been derived from interviews and participant observation conducted intermittently during fieldwork between 2000 and 2005. The paper concludes by discussing the policy implications of using a sustainable development interface analysis in today's Amazonian context

\section{SUSTAINABLE DEVELOPMENT INTERFACES: BASIC CONCEPTS}

\subsection{Social domain}

The development interface is created through encounters between multiple life-worlds, but what parts of a life-world actually constitute an encounter? According to Long (2001, p. 58-59), the analyst first needs to identify social domains in order to tackle the question. Social domains indicate spaces "organized by reference to a central core of cluster of values which, even if they are not perceived in exactly the same way by all those involved, are nevertheless recognized as a locus of certain rules, norms and values implying a degree of social commitment." Typically, a social domain can represent such entities as family, market, state, NGO, religious organization, or producers' association and cooperative. An individual naturally belongs to multiple social domains at the same time within their life-world and draws necessary resources from them to construct a "life project."

A life project is usually embedded in the "socio-technical networks" that endogenously structure actions in actors' life-worlds (PLOEG, 2003, p. 15-19). Through the networks, actors order material resources and reflexively coordinate actions and make individual and collective arrangements (often explained as the interlocking of a number of life projects). By doing so, they are able to "create and defend social and symbolic boundaries" (LONG, 2001, p. 59). These boundaries often shift in the development project process, and this shift further enables the actors to take different types of action and change the characteristics of social domains. Thus, life projects and social domains form a dialectic relationship, and they can result in different institutional arrangements from "those... specifically designed to attain certain economic or political ends” (LONG, 2001, p. 58).

This means that the actors' social and symbolic boundaries have nothing to do analytically with the geographical or ideological boundaries that are often imposed by planners and experts. The so-called areas of conflict such as the frontier settlement area of the Brazilian Amazon have continually emerged because, by interacting with the official boundaries, the involved actors reshape their life projects, social domains, and the boundaries within which they can "mobilize social relations and deploy discursive and other cultural means for the attainment of specific ends" (LONG, 2001, p. 59). Such an area of mobilization is conceptualized as an "arena" that forms a core of the interface.

\subsection{Arena}

In the arena, actors "contest over issues, resources, values, and representations" (LONG, 2001, p. 59). In other words, contestations at interfaces can only be analyzed through an identification of the arena. In the arena, individual actors try to win negotiations over the contenders by arranging and rearranging actions and interlocking life projects. The experience of negotiations, in turn, works to reshape life projects and social domains. In this sense, life projects, social domains, and arenas are all co-generative. This co-generation ultimately determines the characteristics of people's life-worlds, interfaces, and the development project itself.

In the context of the Brazilian Amazon, sustainable development project processes create arenas in which a wide range of actors with distinctive life projects are mobilized. As a result of the mobilization, however, the distinctiveness can be negotiated and possibilities of interlocking these projects emerge to define the terms for their engagement with the project. Naturally, the interlocking projects in the arena could lead to undesirable effects on existing social domains and thus, for example, the ideal of an environmental management project can be substantially compromised. Thus, we often witness situations described as project "failure" and the spread of deforestation. So far, however, in an arena the "failure" is an outcome of the co-generation which it was impossible to predict. In this sense, 
failure can also be conceptualized as a new opportunity for the participants and non-participants to rearrange their life projects and shape new social domains and commitments.

\subsection{Knowledge}

Development sociologists have mainly explored the co-generation between life project, social domain, and arena and the emergence of new opportunities through understanding of encounters between different bodies of knowledge, namely local knowledge and expert knowledge. This is because, in development project processes, interactions among various actors link the everyday life of any project participant to international "epistemic communities" of experts and development professionals (HAAS, 1992), and this linkage helps us to understand the power relations that are in place and changed in the project process. For example, the concept of sustainability is underpinned by scientific expert knowledge, which needs to be somehow "translated" into the local and more practical knowledge in the particular environment (cf. ARCE; LONG, 1994). ${ }^{3}$

According to Arce and Long (1994, p. 79-80), the translation involves an understanding of how certain knowledge is accommodated within the actors' life-worlds or how it widens the distances between different life-worlds. As Schutz (1970) put it, each life-world has its "stock of knowledge" which enables the social actor to interpret the process of sustainable development. Naturally, the knowledge within life-worlds varies according to each actor's experience within social domains and arenas, but it generally indicates the "practical knowledge" needed or a person to live an ordinary life. Such practical knowledge is usually "incoherent," "only partially clear" and "not at all free from contradictions" (SCHUTZ, 1970, p. 75-76). This type of knowledge is usually undermined in sustainable development since the expert knowledge is supposedly more systematic and often more powerful (cf. GIDDENS, 1990).

In principle, there should be no hierarchical order in these different types of knowledge. At interfaces, what we need to observe is a new body of knowledge created through the interactions between practical knowledge and expert knowledge. In many development projects, expert knowledge becomes a

In more traditionally united communities (such as indigenous people's and forest dwellers' communities), sustainable resource management practices have been conducted before such concept existed and, thus, the translation should work the other way around, in orde to disseminate knowledge and local experiences of resource management among experts (SILLITOE; BICKER; POTTIER, 2002). point of reference for the beneficiaries to reflect on their life projects and social domains to take further actions, generating a way to form a countervailing power at arenas against external expert forces. This process, in turn, could enrich expert knowledge to adjust the project design according to the local learning process. In this vein, the interface indicates essentially the "knowledge interface" in which a new body of knowledge emerges.

\subsection{Agency}

Knowledge cannot be separated from the concept of agency, because every actor involved in development intervention is a "knowing, active subject" (KNORR-CETINA, 1981 cited in LONG, 1989, p. 222). In sociology, agency precisely indicates the knowledgability and capability to take action and, according to Giddens (1977, p.75), it works to enable "the stream of actual or contemplated causal interventions of corporeal beings in the ongoing process of events-in-theworld." If we focus on the agency, therefore, "development intervention" not only intervenes in the individuals' life-worlds but equally the individuals' actions intervene in it. In other words, agency is important for the interface analysis of sustainable development because it analytically confirms that the involved actors are able freely to intervene in the events-in-the-world that have been made visible owing to the project implementation.

According to Long (1989, p. 228-231), in order to highlight the working of agency at interfaces, the analyst needs to recognize the importance of "emergent structures" continuously shaped by the actors' actions in the project process. The emergent structures also represent a new body of knowledge, and sustainable development as a product of negotiation should be understood in relation to these structures. In practice, in order to grasp how these structures actually emerge, ethnographic methods are the most effective (LONG, 1989, p. 231). Through the ethnography of sustainable development projects, we are likely to discover that even the community-based or bottom-up projects still seem to be very much top-down, as expert knowledge tends to describe collective needs for beneficiaries, and this knowledge is supposed to be smoothly transferred to the project beneficiaries' practical knowledge.

In sum, using the concepts of life project, social domain, arena, knowledge and agency, we need fully to recognize that development is negotiated in the project processes and that there is always a possibility that new social boundaries 
can be drawn. This is because the project beneficiaries are corporeal actors, and they have wider scope of action in their life-worlds than the specific project framework can assume.

\section{ENCOUNTERS BETWEEN DIVERSE LIFE-WORLDS ${ }^{4}$}

The state of Pará has always had a high deforestation rate in the Brazilian Amazon, ${ }^{5}$ especially in the land settlement projects that have largely been created in the south-east of the state (BRANDÃO; SOUZA, 2006, p. 1). Some environmental historians even suggest that deforestation in the south-east of Pará should be considered as the forefront of global deforestation today (WILLIAMS, 2006, pp. 442-450). This deforestation trend, however, only started in the 1980s. By then, the region had become the center of the Brazil nut economy. For example, an area of nearly 100,000 hectares was demarcated as Poligono dos Castanhais to protect extraction concessions (castanhais) for the owners of the Brazil nut industry in the region in 1984. This area subsequently became the target of the Superintendency for Development of the Amazon (SUDAM) to promote cattle ranching. Between 1984 and 1997, nearly 70 percent of the Brazil nut forest in the region was converted to cattle ranch establishments owned by the former owners of the Brazil nut concessions and cattle companies from the south of Brazil (WATRIN; SAMPAIO; VENTURIERI, 2001). In this conversion process, former nut collectors (castanbeiros) and immigrant farmers (posseiros) began to form syndicates and movements and to squat on castanhais and claim entitlements over pieces of land from the owners. In order to avoid conflicts between the owners of castanhais and the syndicate movements, the Ministry of Agrarian Reform and Development (MIRAD) expropriated 61 castanhais in the area. Six of these castanhais formed the settlement project of Grotão dos Caboclos (hereafter, Grotão) that covered 32,888 hectares in total, which were divided into 670 parcelas in 1988. Grotão was later classified as one of 42 settlement projects monitored by the regional superintendency of the National Institute of Colonization and Agrarian Reform (INCRA) in the southern Pará (EMMI; MARIN, 1997, p. 262).

4 This section draws heavily on a detailed ethnography of the case study settlement by Otsuki (2007).

The annual deforestation rate of Pará has stayed at the same level of approximately 5,500 $\mathrm{km}^{2}$ since 2004. For the most recent coverage on this matter, see "Pará é o Estado com mais municípios na lista de maiores desmatadores," Folha de São Paulo Jan 29, 2009 htttp://www1. folha.uol.com.br/folha/brasil/ult $96 \mathrm{u} 496077$. shtm

\subsection{Posseiros' social domains}

The syndicate movement largely shaped the initial social domains of posseiros in Grotão. Originally, the individual posseiros were from various states, such as Maranhão, Piauí, Bahía, Ceará, Goiás, and Espírito Santo and had little contact with each other before entering the state of Pará. As Grotão became part of the municipality of São Geraldo do Araguaia, which had been split off from Xinguara, these posseiros became members of the Syndicato dos Trabalhadores Rurais (STR) of this municipality. The STR supported the posseiros of Grotão in their collective fight for a hearing by MIRAD to win their settlement project and associated benefits. As in other parts of Pará, the posseiros in Grotão represented a "selfclassificatory political category that referred to a struggle over land" (ESTERCI, 2004, p. 132), and they were strongly united through their struggles to negotiate with the government and also with the owners of castanhais.

The STR's leader was working closely with the pastor of the Church of the Assembly of God, the largest Pentecostal denomination in Brazil. The pastor was from Goiás and he was accompanied by a logger from his home town. The logger could open forests for the squatting posseiros, saw logs and make planks for the posseiros to build their houses and fences. MIRAD granted occupation licenses for the cleared land plots according to the principle of cultivo efetivo e morada habitual, and the logger was considered to be invaluable to the STR.

Soon after Grotão was demarcated, however, the STR became an organization dealing rather in paperwork for credits and pensions, and it no longer offered a strong unifying principle for the posseiros. Each posseiro obtained a land plot and became a "small producer" and thus started to be extremely busy developing subsistence farming and cattle ranching on the plot. At this time, the logger established a sawmill in the central village of Grotão, and started to expand his own business regardless of the posseiros' claim to land. The immediate concerns for posseiros after the land demarcation were rural credits and basic and social infrastructure. In short, they all started to individualize their new life projects.

In 1993, with support from the municipal government of São Geraldo do Araguaia and a Brazilian NGO called Action for Sustainable Development in Amazonia (ASDA), the pastor founded an association of small farmers in Grotão (hereafter, the Association) with which more than 300 posseiros throughout the region were affiliated. ${ }^{6}$ The Association soon became the organizational base for

The names of organizations or individuals used in the case study are pseudonyms. 
posseiros to ask for rural credits from the Amazon Bank. ${ }^{7}$ The pastor acted as the representative of the mayor of São Geraldo do Araguaia and consolidated the relationship between ASDA, the municipal government, and the Bank. At the same time, his presence worked to attract many evangelical posseiros to Grotão, and they built the largest church building in the settlement.

In 1997, officially 800 families had settled in the central village of Grotão, and the population in the interior was rapidly increasing, so much so that a new municipality called Piçarra, about $40 \mathrm{~km}$ from Grotão, was split off from São Geraldo do Araguaia with 8,000 inhabitants. The demand for schools, electricity, better roads, public transport, and health posts was increasing, and the settlers elected a town councilor from Grotão in the 1996 general election. The councilor was the close ally of the pastor in the Association, and his official representation at the municipal council was thought to be beneficial for the Associates in carrying out their projects.

\subsection{NGO intervention: community agroindustry}

Through contact with the pastor and the councilor, ASDA sent a técnico to Grotão in 1996 to promote a community agroindustry project. Between 1995 and 2003, the Brazilian government and international development organizations such as the World Bank vigorously promoted community-based natural resource management in the Brazilian Amazon within the framework known as Demonstration Projects - Type A (PDA), funded by the Brazilian Tropical Rainforest Fund (PPG7). ${ }^{8}$ ASDA obtained this PDA funding, and was going to use it for the community agroindustry projects in four pilot communities in Pará. Grotão was one of them.

Prior to the agroindustry project, the Association had tried to implement agroforestry systems in the Associates' plots with several técnicos from ASDA, which turned out to be a manifest failure. At that time, the Associates were vigorously using the initial rural credits to develop milk production, and fruit or subsistence crop plantations in agroforestry systems as introduced by técnicos were not their priority. Many of the Associates thus

As the Amazon Bank required organizational affiliation for small farmers to apply for a credit source established in 1989 as the Constitutional Fund of the Finance of North Region (FNO), the 1990s saw a rapid increase in the number of small farmers' associations linked to settlement areas in Amazonia, which were practically non-existent in 1990 (COPATIORO, 2004).

The fund was administered by the World Bank and the Brazilian Ministry of Environment. See Kolk (1996) for details. stopped participating in agroforestry. The pastor, however, attended a weeklong training course for PDA community leaders at ASDA's headquarters in the state capital Belém, and he was persuaded to promote banana plantation in Grotão and establish the agroindustry to process bananas and produce banana flour. Back in Grotão, he convinced about 270 Associates to participate in the agroindustry project. The councilor also supported the plan and insured continuous NGO intervention.

In 2000, the so-called banana factory was inaugurated. According to an extension worker, this agroindustry was "explored by the Associates" and thus was a community initiative. The inauguration ceremony was attended by politicians of surrounding municipal governments, Amazon Bank officials, and coordinators and extension workers from ASDA and the state agricultural extension agencies. At the ceremony, they took turns to make speeches presenting the factory as an example to be followed by other communities since it was the first example of "self-organized sustainable production activity" in the region (according to a coordinator from ASDA). After the ceremony, ASDA sent several nutritionists to provide training courses on sanitary matters to the factory workers and cooking courses to local women who were expected to use the banana flour in the dishes.

The factory, however, soon started to face problems, explained mainly as financial ones, so that in 2001 it had occasionally to suspend operations. In 2003, the factory operations stopped permanently. The Association had only 45 members then, as many left the project to concentrate on the individual credit projects with the Bank, mainly to consolidate cattle businesses.

The banana project made it evident how the previous social domains of posseiros had changed in the settlement. By this time, the population of Grotão and the surrounding settlement projects was nearly 6,000, and the posseiros were no longer the major part of the population. Many of them had become proprietors, employing newly arrived rural workers, or passing on properties to their sons and starting non-farm businesses such as cattle trading and retailing. The Association had already fragmented because of the diversified interests among the settlers who no longer shared the same collective ambition of obtaining land plots and credits, and improving infrastructure through the Association. The factory's closure embodied this fragmentation, but ASDA explained the apparent failure of the agroindustry in Grotão somewhat differently, as we see below. 


\subsection{Técnicos in arenas}

Técnicos usually explained the non-participation of Associates in the community-based project as the lack of consceitnização. According to one extensionist, the producers in Grotão did not appreciate agroforestry and the importance of community agroindustry because they were pursuing only individual interests in terms of extensive cattle ranching. As Sheridan (2007) shows in the case of the United States, ranchers are very often in conflict with conservationists, since they are unquestionably destructive in the context of nature conservation. In the Amazonian frontier settlements, similar conflicts can always be found in arenas between the técnicos who are supposed to promote sustainable resource management and the settlers who are eager to become fazendeiros.

Cattle ranching in the frontier settlements is usually individualistic because its production unit is limited to fenced individual property, and the rural credit program is applied to each proprietor. Although ranchers cooperate with each other in arranging collection of milk or vaccination of cattle, their activities are not usually considered to be community-based. Técnicos needed to promote the "real" community-based projects, and cattle ranching simply did not fit into the ideal framework. Instead of questioning the relevance of the framework to the specific settlement context, however, they complained that these new ranchers needed concsientização although concrete proposals to provide this concsientização were never elaborated.

Técnicos are indeed in a difficult position, bridging the world of settlers and the world of the state, Bank, and NGO (cf. ARCE, 1989). Those who worked with the Association in Grotão were usually on loan from the state agricultural enterprise (EMATER) or Agricultural Secretariat (SAGRI), contracted per project by ASDA in agreement with these official employers. Therefore, they had to follow the instructions of the project, while understanding the true demands of their beneficiaries. After the failure of the banana factory, for example, one técnico proposed to turn the Association into a cooperative and build a milk processing unit for the members. As the Associates had been complaining about the low price paid by the existing processing industries, they immediately mobilized themselves to place a project proposal before ASDA. In the end, however, the ASDA coordinators did not accept the proposal and eventually sent the técnico to another project area. Consequently, the negotiation between the Association and ASDA headquarters stopped.
As this example shows, the técnicos are often caught between the power of demanding beneficiaries and the power of decision-makers who control funding outside the técnicos' domains of influence. Consequently, although they are at the center of arenas in the agroindustry project, they are unable to take control of the project process.

\subsection{Expert systems}

The NGO coordinators who appoint técnicos to work in certain pilot communities are those who apply the particular meaning of sustainable development crafted in funding and political agencies such as the World Bank and United Nations, or the Ministry of Environment. The coordinators present themselves to these agencies as experts in the local reality, although they need to simplify the reality substantially in the process. The simplification works to situate the local NGO coordinators in "expert systems," that is, "disembedding mechanisms of modernity" which work to "lift out social relations from local contexts of interaction and their restructuring across indefinite spans of timespace" (GIDDENS, 1990, p. 21).

In obtaining PDA for Grotão and three other pilot communities, the ASDA coordinators had to present the local reality within the funding requirements. They established the image of the "poor cutting down trees" in this process, and underlined the importance of establishing sustainable income generation schemes in order to prevent the poor subsistence farmers throughout the Amazon from participating in logging and the illegal timber trade. This was because PDA required an innovative approach to tackle poverty and establish effective natural resource management. Community agroindustry fits perfectly in this storyline.

As a model, the production chain development of bananas in Grotão should have benefited the group of small farmers who were supposedly suffering from the lack of opportunities in the interior frontier settlement. In reality, however, the project rather worked to fragment the group, because it enabled the farmers spontaneously to identify with other opportunities than what the project promised. This gap happened as the expert systems assumed a type of discourse that could work as a template: "sustainable business promotion" (MINISTRY OF ENVIRONMENT; PPG7, 2002). This entrepreneurial focus placed the community-based projects neatly within the neo-liberal policy environment, reflecting an image of the new development professionals who emerged from business communities, especially in the United States. The local experts had to 
share this image with these international experts, and they eventually stopped questioning the local specificity of their business-oriented projects.

For example, when the production chain model embodied as the banana factory in Grotão was presented to the donor community at the World Bank in 2003, the Bank officials told the project coordinator from ASDA to develop a business plan. This was a new concept for ASDA. In 2004, the coordinators organized a workshop for NGO workers and cooperative leaders based in Pará to learn "how to make a business plan" (UNCTAD, 2003). At the same time, they started to seek business consultants in the south of Brazil for project management. This increasing talk of "business" at the local NGO was certainly the product of encounters between local and international experts and their distinctive social domains.

The business principle makes the organizational future of NGOs one of the criteria of project evaluation (UNCTAD, 2003, p. 3). Promoting grassroots businesses among farmers' associations and cooperatives in pilot communities means that NGOs need continuously to seek commercial investments to run and expand these businesses. The future-orientedness of business principles resonates with expert knowledge generated in expert systems (PLOEG, 2003, p. 230-232), underpinned by the logic of calculated planning of both environmental conservation and economic development. In this process, the realities experienced by the Amazonian settlers and their practical knowledge are simplified and misrepresented and yet legitimized for the project applications.

\subsection{Discussion}

The case study shows that even in a micro-community project such as the banana factory in Grotão we can see complex layers of interfaces, from the posseiros' struggles to the World Bank funding negotiations. These interfaces demonstrate principally the process of evolving knowledge interfaces: first, posseiros' practical knowledge to survive in the new settlement has been enriched through negotiation with governmental agencies such as MIRAD and INCRA, which forced them to consolidate the syndicate movement. Second, the requirement to apply for rural credit to the Amazon Bank to develop productive activities made these posseiros reorganize themselves to create the Association. In this process, the individual posseiros started to accumulate knowledge that could be used in the pursuit of new life projects. With this knowledge, they tacitly evaluated the community-based agroindustry project and eventually chose not to participate in it.
By interacting directly with these posseiros as beneficiaries, técnicos noticed that a process of individualization of collective commitments was taking place and, therefore, the direction of the project should have been changed. The técnicos' ability to deal with this emerging situation, however, was taken to be "practical" and not sufficiently "expert" in terms of the project ideal. At the same time, the técnicos did not deny the ASDA coordinators' expert knowledge, since they knew that their job was to disseminate that very knowledge. If the project did not run as expected, they blamed the settlers' culture, referring to abstract concepts such as conscientização, rather than questioning specific project assumptions. Furthermore, the coordinators' expert knowledge was nurtured through the negotiations over funding with the international experts and, therefore, they cannot be blamed for ignoring the practical knowledge, as they have also been forced to be a part of certain disembedding expert systems.

Why do experts (or expert systems) tend to overlook the emerging new practical knowledge that becomes visible in the project process? As Arce and Long (1994, p.81) argue, it may be because the area of ignorance is often systematically "reproduced through the dynamics of knowledge interfaces" and, therefore, the experts do not realize the necessity of acknowledging the partiality of the beneficiaries and the técnicos' practical knowledge (cf. HOBART, 1993). The reproduction of the ignorance currently takes place in parallel with the reproduction of expert systems, through interactions between experts from different life-worlds. These experts arrange for certain knowledge to be represented and conceal other bodies of knowledge at the same time. Looking into knowledge interfaces is, therefore, an effort to recover such concealed knowledge and question the existing knowledge claims originated by the expert systems.

Recognizing different bodies of knowledge, we can also rethink the roles of NGOs. NGO coordinators as local experts are pivotal "in constructing the frameworks that define the criteria through which collective demands can be defined and problematized" (CHERNELA, 2005, p. 630), and this fact reminds us that the presentation of collective demands is not always made by the members of the collective concerned. NGOs are principally brokers who often define and modify terms for local engagement on behalf of both beneficiaries and funding agencies. They can either consciously use this characteristic to develop their activities or reflexively change the terms for involvement with local communities and global epistemic communities. In any case, knowledge interfaces demonstrate the gap between the real demand of the beneficiaries and the demand defined by 
local experts who are in constant contact with international experts. In order to facilitate local engagement with the ideal of sustainability, we need to find a way to narrow it.

To this end, we need to rethink the historical background of the development project concerned, especially in terms of flows of information and funds, the agency of all the actors involved including non-experts such as beneficiaries and técnicos, and different claims and representations that have been made. Even in a micro-project such the one shown in this case, the complexity of the project process and the building of layers of interfaces are obvious. If we want to learn from examples of "failure," we need to think seriously about what could have been done to appreciate concealed bodies of knowledge and action outcomes that tacitly built emergent structures and upset the planned framework.

\section{CONCLUSION}

The preceding discussion prompts the presentation of some policy implications of conceptualizing sustainable development interfaces in today's Amazonian context.

1. Sustainable development is a kind of macro-statement, which is undergirded by expert knowledge. Thus, in order to promote this as a local initiative, as seen in community-based natural resource management projects, we need first to grasp "problems" properly, according to how the community members describe them or by looking for an existing pattern of natural resource management that is compatible with the project proposal. For example, in the case of Grotão, a proposal for sustainable ranching should have been available or the initiative for milk production should have been taken more seriously. We should also have considered a project for sustainable agriculture that is compatible with pasture management.

2. We need to understand what community-based project as a collective arrangement actually means to different actors. In the frontier settlement like Grotão, the idea of the united community needed to be fabricated to some extent because the settlers had already embarked on individual life projects before the project was implemented. Ideally, the project design needs to be more flexible, recognizing the dialectic process of individual project participants' agency to pursue both individual life projects and collective commitment by reshaping the social domains. More specifically, individual property-based resource management programs, linked to each credit project, should be readily available, and the fabrication of community commitment based on the sharing of these individualbased project experiences.

3. Local knowledge does not have to be traditional or indigenous, as often implied, but the entire experience of development projects for the beneficiaries and técnicos should be recognized as a body of knowledge that is situated against the expert knowledge at the interface. Also, expert systems need to have a mechanism to learn from this local knowledge, described by the beneficiaries or the sympathetic fieldworkers (including técnicos). In this sense, in many cases the roles of técnicos need to be appreciated and they need to be part of the larger capacity building agenda in the Amazon.

4. We should also rethink the legitimacy of NGOs and the potential of local governments for promoting sustainable development to utilize the existing institutional frameworks that can be used to support emerging spaces of negotiations.

Although this paper has concentrated on NGO intervention, the interface analysis can also be applied on a larger scale to environmental policy intervention, or workings of social movements and their contenders in claiming accesses and rights to natural and other resources. The overall goal of this analysis is to emphasize that any development and environmental project creates encounters, and the encounters generate micro-dynamics of ordering, create new structures, and influence different bodies of knowledge. Thus, sustainable development as a project needs to have various channels for adjustment to the implementation process and should aim to enhance the social capacity to rework sustainable development frameworks.

\section{REFERENCES}

ARCE, A. The Social Construction of Agrarian Development: A Case Study of Producer-Bureaucrat Relations in an Irrigation Unit in Western Mexico. In. LONG, N. (Ed.). Encounters at the Interface: a perspective on social discontinuities in rural development. Wageningen: Wageningen University, 1989. p. 11-51. 
ARCE, A. Value contestations in development interventions: community and sustainable livelihoods approaches. Community Development Journal, v. 38, n. 3, p. 199-212, 2003.

ARCE, A.; LONG, N. Re-positioning Knowledge in the Study of Rural Development. In. SYMES, D.; JANSEN, A. J. (Eds.). Agricultural Restructuring and Rural Change in Europe. Wageningen: Wageningen University, 1994. p. 75-86.

BOOTH, D. (Ed.). Rethinking Social Development: Theory, Research and Practice. Harlow: Longman, 1994.

BRANDÃO JR., A.; SOUZA JR., C. Desmatameto nos Assentamentos de Reforma Agrária na Amazônia. Belém: Imazon, 2006. (O Estado da Amazônia, 7.

BROWDER, J.O.; PELDOWSKI, M.; WALKER, R.; WYNNE, R.H.; SUMMERS, P.; ABAD, A.; BECERRA-CORDOBA, N.; MIL-HOMENS, J. Revisiting theories of frontier expansion in the Brazilian Amazon: A survey of the colonist farming population in Rondonia's post-frontier, 1992-2002. World Development, v. 36, n. 8, p. 1469-1492, 2008.

BROWDER, J. O.; GODFREY, B. J. Rainforest Cities: Urbanization, Development, and Globalization of the Brazilian Amazon. New York: Columbia University Press, 1997.

CHERNELA, J. M. The Politics of Mediation: Local-Global Interactions in the Central Amazon of Brazil. American Anthropologist, v. 107, n. 4, p. 620-631, 2005.

CLAY, E.; SCHAFFER, B. (Eds.). Room for Manoeuvre: an exploration of Public Policy Planning in Agricultural and Rural Development. London: Heinemann Educational Books, 1984.

COPATIORÔ. Políticas de crédito para a agricultura familiar. Conceição do Araguaia: Copatiorô-DFID, 2004. (Série Políticas Públicas, 3).

D’INCÃO, M. A.; SILVEIRA, I. M. da. (Eds.). A Amazônia e a crise da modernização. Belém: Museu Paraense Emílio Goeldi, 1994.

ELLIOT, J. An introduction for sustainable development. London: Routledge, 1999.

EMMI, M. F; MARIN, R. E. A. De posseiros aos assentados: Precaridade das Ações Fundiárias no Sudeste do Pará. In. COELHO, M. C. N.; COTA, R. G. (Eds.). 10 Anos da Estrada de Ferro Carajás. Belém: UFPA/NAEA, 1997. p. 251-273.
ESTERCI, N. The Peasantry and the Church on the Brazilian Frontier: The Significance of the Alliance and its Repercussions. In: NUGENT, S.; HARRIS, M. (Eds.). Some Other Amazonians: Perspectives on Modern Amazonia. London: Institute for the Study of the Americas, 2004. p. 128-144.

FEARNSIDE, P. M. Land-Tenure Issues as Factors in Environmental Destruction in Brazilian Amazonia: The Case of Southern Pará. World Development, v. 29, n. 8, p. 1361-1372, 2001

FEARNSIDE, P. M. Deforestation in Brazilian Amazonia: History, Rates, and Consequences. Conservation Biology, v. 19, n. 3, p. 680-688, 2005.

GIDDENS, A. New Rules of Sociological Method. London: Hutchinson, 1977. GIDDENS, A. The Consequences of Modernity. Stanford: Stanford University Press, 1990.

HAAS, P. M. Introduction: Epistemic Communities and International Policy Coordination. International Organization, v. 46, n. 1, p. 1-35, 1992.

HOBART, M. (Ed.). An Anthropological Critique of Development: The Growth of Ignorance. London: Routledge, 1993.

HOCHSTETLER, K.; KECK, M. Greening Brazil: Environmental Activism in State and Society. Durham: Duke University Press, 2007.

KOLK, A. Forests in International Environmental Politics: International Organizations, NGOs and the Brazilian Amazon. Utrecht: International Books, 1996.

LEEUWIS, C. Re-conceptualizing Participation for Sustainable Development: Towards a Negotiation Approach. Development and Change, v. 31, n. 5, p. 931-959, 2000.

LONG, N. Encounters at the interface: a perspective on social discontinuities in Rural Development. Wageningen: Wageningen University, 1989.

LONG, N. Development Sociology: Actor Perspectives. London: Routledge, 2001.

LONG, N.; LONG, A. Battlefields of Knowledge: The Interlocking of Theory and Practice in Social Research and Development. London: Routledge, 1992.

THE MINISTRY OF ENVIRONMENT; PPG7 (Eds.). Negócios para a Amazônia Sustentável. Brasília: MMA, 2002. 
NEPSTAD, D.; AZEVEDO-RAMOS, C.; LIMA, E.; MCGRATH, D.; PEREIRA, C.; MERRY, F. Managing the Amazon Timber Industry. Conservation Biology, v. 18, n. 2, p. 575-577, 2004.

NEPSTAD, D; MCGRATH, D.; ALENCAR, A.; BARROS, A. C.; CARVALHO, G.; SANTILLI, M.; VERA DIAZ, M. del C. Frontier Governance in Amazonia. Science, v. 295, p. 629-631, 2001.

OTSUKI, K. Paradise in a Brazil Nut Cemetery: sustainability discourses and social action in Pará, the Brazilian Amazon. 2007. PhD (Dissertation) - Wageningen University, Wageningen, 2007.

PERZ, S. The Changing Social Contexts of Deforestation in the Brazilian Amazon. Social Science Quarterly, v. 83, n. 1, p. 35-52, 2001.

PLOEG, J. D. van der. The Virtual Farmer: Past, Present and Future of the Dutch Peasantry. Assen: Van Gorcum, 2003.

RUSCHEINSKY, A. (Ed.). Sustentabilidade: uma paixão em movimento. Porto Alegre: Sulina, 2004.

SCHERIDAN, T. Embattled Ranchers, Endangered Species, and Urban Sprawl: The Political Ecology of the New American West. Annual Review of Anthropology, v. 36, p. 121-138, 2007.

SCHUTZ, A. On Phenomenology and Social Relations. Chicago: The University of Chicago Press, 1970.

SCHMINK, M.; WOODS, C. Contested Frontiers in Amazonia. New York: Columbia University Press, 1992.

SILLITOE, P.; BICKER, A.; POTTTIER, J. (Eds.). Participating in Development: Approaches to Indigenous Knowledge. London: Routledge, 2002.

UNITED NATIONS CONFERENCE ON TRADE AND DEVELOPMENT. How to Make a Business Plan? Geneva: UNCTAD, 2003.

WATRIN, O. dos S.; SAMPAIO, S. M. N.; VENTURIERI, A. Dinâmica da Vegetação e do Uso da Terra no Polígono dos Castanhais, Sudeste Paraense, Usando Geotecnologias. Geografia, v. 26, no. 3, p. 37-54, 2001.

WILLIAMS, M. Deforesting the Earth: From Prehistory to Global Crisis, An Abridgment. Chicago: The University of Chicago Press, 2006.

Texto submetido à Revista em 23.10.2009 Aceito para publicação em 15.03.2010 